\title{
Contributo de novo modelo editorial da revista para a formação e a investigação em Medicina Geral e Familiar
}

\author{
Alberto Pinto Hespanhol*
}

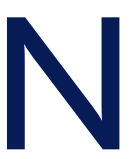
o momento em que redijo este Editorial, é imperioso endereçar os meus agradecimentos à Direcção da Associação Portuguesa de Medicina Geral e Familiar (APMGF) pelo convite que me dirigiu para pertencer ao Corpo Editorial da Revista Portuguesa de Medicina Geral e Familiar (RPMGF), na qualidade de seu Editor Chefe.

Também gostaria de expressar a todos os Diretores da RPMGF e seus Corpos Editoriais, que me antecederam desde a sua publicação em 1984, um muito obrigado pela experiência que me foram proporcionando como membro do Conselho Científico, Revisor, Autor e Leitor desta Revista.

Espero poder corresponder às expectativas que os sócios e os membros dos órgãos da APMGF, os membros dos Conselhos Editorial e Científico, os Revisores, os Autores e os Leitores da RPMGF esperam do Editor Chefe, em especial levar a cabo o objetivo fundamental desta sua revista que passo a citar “...A revista visa contribuir para o desenvolvimento daespecialidade de MGFe para a melhoria dos Cuidados de Saúde Primários (CSP) através da publicação de artigos de investigação...e outros..." (Disponível em: http://www.rpmgf.pt/ojs/ index.php/rpmgf/about/editorialPolicies\#focusAndScope).

Na realidade é fundamental fazer Investigação clínica, a nível dos CSP, tal como é aconselhado no Plano Nacional de Saúde 2011-16 na área da Investigação Científica, pelo Prof. João Lobo Antunes.

Alguns dos benefícios da Investigação clínica estão contidos num documento do Health Cluster Portugal, "Inovação e competitividade na Investigação Clínica”, de Março, 2010e que passo a referir:

“ ... A nível dos Cuidados de saúde: Contribuição para a qualidade da atividade assistencial, impacto na organização e capacitação das unidades de saúde e acesso precoce a fármacos inovadores;

A nível Educacional e científico: Oportunidade dos investigadores colaborarem com os seus pares em programas nacionais e internacionais, promoção da formação em metodologias de investigação e criação de ambiente propício ao desenvolvimento projetos originais;

A nível Económico - Criação de mais postos de trabalho..."

Na reflexão que se tem vindo a realizar sobre a investigação clínica não é possível deixar de citar um artigo do $\mathrm{N}$ Engl Lmed. 19796 de Dec; 301 (23): 1254-9, intitulado “O investi-

*Editor Chefe da Revista Portuguesa de Medicina Geral e Familiar gador clínico como uma espécie em extinção" da autoria de Wyngaarden JB, em que já se discutiam as dificuldades do médico-cientista, as quais no momento presente poderiam ser elencadas do seguinte modo:

- O progresso científico obriga a constante atualização absorvendo muito tempo, tendo o médico dificuldade em conciliar investigação e assistência

- Os modelos exigentes de gestão, de indicadores de saúde e de metas assistenciais, limitando a disponibilidade dos clínicos para investigação;

- Fraca recompensa académica e dificuldades de financiamento;

- Ausência de unidades de suporte à investigação e de política de investigação como estratégia própria das unidades de saúde

Também se espera que, com a preciosa colaboração dos dois Editores Adjuntos (Dr. Tiago Maricoto e Professor Paulo Santos), o Editor Chefe conduza os membros dos órgãos do Corpo Editorial, como um maestro de uma organização baseada na estrutura não hierarquizada das orquestras sinfónicas (Drucker PF.Peter Drucker on the Profession Management., Boston: The Harvard Business Review book series, 1998), indicando os grandes objetivos a implementar num novo modelo editorial da Revista, referidos pelo seu Director, Dr. Rui Nogueira, no seu último Editorial:

- manter o rigor científico e a independência total e absoluta

- separar de forma clara a função diretiva da função editorial

- fomentar a formação contínua de novos editores

- incentivar a publicação on-line e a edição de artigos originais em inglês

- promover a parceria para publicação de artigos originais em revistas de referência.

(Disponível em <http://www.rpmgf.pt/ojs/index.php/ rpmgf/article/view/12158/11336>)

Os médicos sabem que enquanto as atitudes da sua profissão vão perdurando com uma certa estabilidade ao longo do tempo, os conhecimentos e as aptidões que adquiriram durante a sua formação vão-se desatualizando.

Por isso, a auto atualização dos médicos, ou seja a necessidade que têm de maximizar o seu próprio potencial, domina e motiva na realidade os seus comportamentos, nunca estando completamente satisfeita

Assim, no âmbito da Formação Contínua da Especialidade de MGF, é minha convicção que se hoje pedíssemos aos Médicos de Família para nomear as Revistas que recomendariam, a RPMGF seria certamente uma das referidas. 